\title{
Welfare and world money: the domestic foundations of currency internationalisation
}

\author{
Randall Germain ${ }^{1}$ \\ Published online: 24 November 2020 \\ (c) Springer Nature Limited 2020
}

\begin{abstract}
This essay explores the domestic foundations of currency internationalisation. I consider how a state that internationalises its currency might sustain the domestic economic and social costs of doing so. In particular I highlight the role of welfare provision as a neglected element of the domestic political economy of currency internationalisation. I examine the trajectory of welfare provision in Britain (18701930), the United States (1950-2020) and China (2000-2018), and use this data to consider some of the ways in which these costs might be related to the question of issuing world money. In this essay I suggest, first, that our conceptual framework for understanding currency internationalisation is strengthened when we consider welfare provision as an important element of the domestic foundation of issuing world money; and, second, that it is unclear whether the current level of welfare provision in China is adequate to meeting the costs to China of fully internationalising its currency as world money. This framework generates further insights about how China's challenge to American monetary leadership remains incomplete, and provides another angle of vision by which we might assess the multifaceted foundations of US dollar domination in the global political economy.
\end{abstract}

Keywords Currency internationalisation $\cdot \mathrm{RMB} \cdot$ Sterling $\cdot$ US dollar $\cdot$ Welfare provision · World money

\section{Introduction}

This essay examines the domestic foundations of currency internationalisation, a term most often used to describe a process by which national money acquires a global role (e.g. Thimann 2008; Chey 2013; Angrik 2018; Eichengreen et al. 2018; Cohen 2019). While the majority of analyses of this process privilege the international economic and political conditions which facilitate a currency's use outside

\section{Randall Germain}

randall.germain@carleton.ca

1 Department of Political Science, Carleton University, Ottawa, Canada

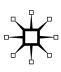


its home jurisdiction (e.g. Andrews 2008; Helleiner and Kirshner 2009), internal or domestic factors have not been ignored. Included here are usually some combination of the degree of liberalisation of the home economy, the commitment to currency convertibility, the extent of capital controls, the regulations surrounding the capital account, the general condition of economic 'openness', and the interests of domestic players connected to the financial system (e.g. Helleiner and Malkin 2012; Helleiner and Kirshner 2014; Lombardi and Wang 2015; McNally and Gruin 2017). All of these are significant aspects of currency internationalisation, but in what follows I wish to draw attention to a neglected feature of this process, namely the development of welfare provision to address the economic and social dislocation that can accompany the global use of a currency outside its borders. My intent is to connect a broader array of domestic political factors to a currency's global role, thereby deepening our understanding of the underlying organisation of international monetary order.

The principal claim I advance is that there is value in paying more attention to how a state that issues what I will call 'world money' negotiates the costs to its economy of running such a currency. Running a world money, in other words, requires more than instilling confidence in the external value and liquidity of a national currency and successfully liberalising its economy. Precisely because world money circulates throughout the global economy, states that have issued such a currency eventually run large and persistent trade, current or capital account imbalances which impose costs on some domestic groups. In Britain, which ran both trade and capital account deficits through much of the nineteenth century and especially after 1870 (Imlah 1958/1969: 70-75), a welfare system began to develop from the 1870 s onwards that ameliorated at least some of the trade-related costs incurred as a result of sterling's role as world money. In the US during the Bretton Woods period, important strides were made to help unskilled manufacturing labour and other lowincome groups cope with some of the effects of large balance of payments deficits arising out of the global role of the dollar, building on the rudimentary welfare provision associated with President Roosevelt's New Deal initiatives. Today, as the process of RMB internationalisation gathers pace, it is unclear whether China's political system can develop the kind of off-setting welfare provision historically associated with running a world money. By developing a more comprehensive and integrated theoretical framework for understanding currency internationalisation, we can better assess the challenge to the prevailing international monetary order posed by China and the growing global role of its currency.

The article proceeds in three steps. First, using the literature on RMB internationalisation as my entry point, I establish how domestic factors have been considered in our understanding of this process, and move to broaden our consideration by returning to the work of early pioneers of scholarship on the political economy of international money. In particular, I follow the lead of Susan Strange to highlight precisely how and why we must pay attention to the adjustment costs that are associated with issuing world money. Second, I explore the development of welfare provision in the UK, USA and China as a first cut to consider its potential explanatory value. Historically, states which issue world money have also developed welfare programmes that have helped to meet these costs, even though such programmes did not arise 
only or even directly from a concern with the global role of their currencies per se. Finally, I reflect on how a consideration of welfare provision adds to our understanding of the phenomenon of currency internationalisation, and especially its domestic foundations.

\section{The political economy of world money: conceptual connections ${ }^{1}$}

Not all currencies are created equal, and few circulate to any meaningful extent outside their home jurisdiction. Among those that do, there is a hierarchy at play which has ensured that a very small subset of such currencies plays an outsized role in the international monetary system (Strange 1971b; Cohen 1998; Thimann 2008; Cohen and Benney 2014). Although they are usually referred to in the literature as international currencies, I think it is more accurate to call these currencies world money, in deference to their historically significant role in helping to shape the organisation of the global political economy. This helps us to distinguish between those currencies which circulate internationally as part of the instrumentality of international trade, and are even used by governments for official purposes, and those which have a more significant weight in the organisation and operation of the global political economy. Others have noted this distinction by calling these important monies a 'top currency' (Strange 1971b; Cohen 1998), or a 'key currency' (Helleiner 2017). In any case, all agree that historically there have only ever been a handful of such currencies at any point in time, and they have been associated with the leading political and economic powers of the day. ${ }^{2}$ Since about 1850 , with the exception of the interwar period, the global economy has supported only one world money at a time: the pound sterling between about 1850 and 1914 (and certainly between 1870 and 1914) and the US dollar since 1945 (Feis 1930/1964; Cohen 2019). ${ }^{3}$

In what follows I shall consider world money as a currency which has a significant global footprint, and which therefore carries an outsized weight in the organisation and operation of the global political economy. Following Thimann (2008) and Cohen and Benney (2014), there are at the current time only two currencies which we can consider to be world money: the US dollar and the euro. But there are strong arguments which suggest that between these two currencies the euro is too weak institutionally to be considered a genuine rival, leaving the world reliant on the US dollar as its leading world money (Germain and Schwartz 2014). With the determined efforts of China to internationalise the RMB, however, some now claim that it is the next challenger for the status of world money (e.g. Subramanian 2011; Chin

\footnotetext{
1 This section draws on work co-authored with Herman Mark Schwartz (Germain and Schwartz 2014, 2017).

${ }^{2}$ For work in the field of IPE which examines the international organisation of money and finance from such a vantage point, see Braudel (1979/1984), De Cecco (1974), Germain (1997), Helleiner (1994), and Langley (2002).

3 Some have suggested that the global economy can support more than one international currency at a time, but they rely on narrower conception of an international currency than I use here (e.g. Eichengreen and Flandreau 2012; Eichengreen et al. 2018).
} 
2014). This is where the debate over currency internationalisation can add value to our understanding of change within the global political economy, by considering how far the RMB is or might shortly become able to act as world money.

The existing literature on RMB internationalisation largely parallels the treatment of currency internationalisation more generally, by focusing on the external economic constraints and functions performed by such a currency. Jenkins and Zelenbaba (2012), for example, use a taxonomy of roles for an international currency, first developed by Cohen (1971), to assess the efforts to internationalise the RMB. ${ }^{4}$ Bowles and Wang (2013) provide a thorough but similarly categorised assessment of these policies, which they see originating in China's response to the vulnerability of its exports to fluctuations in the value of the dollar (cf. Kwon 2015: 89; McNally and Gruin 2017: 611-12). For them, RMB internationalisation is a protective policy that will be successful to the extent that a sustainable, long-term path toward liberalisation of the capital account is achieved. Domestic considerations only surface in their comment that domestic capital markets are not yet deep or liquid enough to sustain full liberalisation (Bowles and Wang 2013: 1375; see also Hung 2013).

Some analyses of RMB internationalisation, however, do incorporate domestic political considerations, in one of two ways. On the one hand, many scholars at some point in their analysis conclude that the question of regime stability places a limit on how far the state can move to liberalise China's financial system. Cohen (2012), for example, concludes his analysis of the future of the RMB by noting that rigidity in China's political system places important barriers in the way of successful internationalisation (see also Eichengreen et al. 2018: 191-93; McDowell and Steinberg 2017: 810-14; Cohen 2019: 155-60). On the other hand, questions connected to economic growth can foreshadow the kinds of distributional questions I pursue below, primarily because the size of China's economy is directly related to the prospect of the RMB becoming an international currency. Ito (2010), for example, examines the demographic factors shaping China's future economic growth, but without considering how China might use social policy to respond to these pressures. Wang (2014) and Steinberg (2014) each touch on domestic considerations, yet neither explores the social dimension of China's domestic politics. They focus more narrowly on how domestic economic considerations intersect with China's global monetary ambitions. ${ }^{5}$ Similarly, Helleiner and Malkin (2012) consider domestic sectoral influences in China's currency internationalisation strategy, but do not frame these influences in terms of social policy. ${ }^{6}$ Essentially, the literature on RMB

\footnotetext{
4 This taxonomy describes the functions of an international currency in terms of a two by three matrix that illustrates how public and private agents use a currency for international transactions. It is widely deployed in the literature. In addition to the work cited above, see Cohen (2012), Chey (2013), Eichengreen (2015) and Liao and McDowell (2015).

${ }^{5}$ More broadly, Helleiner and Kirshner (2014) reflect prevailing analyses of the politics of RMB internationalisation insofar as the contributors are mostly concerned with the political effects of liberalisation of the current account, and how such efforts impinge on China's evolving international monetary relations.

${ }^{6}$ Wang et al. (2015) and Kwon (2015: 85-88) similarly raise domestic considerations in the form of institutional factors, but without extending their analysis to welfare provision. Chey (2013) touches on domestic political issues as an important determinant of what he identifies as international political power, but also without incorporating welfare systems as a potential product of political negotiation. And
} 
internationalisation follows in the footsteps of earlier debates on the euro, in which the primary focus concerns the international arrangements that characterise currency internationalisation. ${ }^{7}$

Without ignoring the factors that have been emphasised to date in the literature, I want to highlight instead an understudied domestic feature that I believe makes an important contribution to how we can understand the political sustainability of the process of currency internationalisation. To do this, I return to three early theorists of the political economy of money whose ideas can be combined to take account of domestic factors in a more comprehensive framework: Robert Triffin, Charles Kindleberger and especially Susan Strange. ${ }^{8}$ I connect three different claims which they make to frame my understanding of the political economy of currency internationalisation.

The first claim I wish to emphasise comes initially from Robert Triffin, who recognises that money plays a different role when it moves from a national to a global context. Triffin's signal contribution here is to understand that some form of world money is needed to transmit demand from a leading national economy to the global economy in order for the global economy to grow. In his view, a national money could not both anchor the world's exchange-rate system by being fixed to a nonexpansionary commodity such as gold, and at the same time provide the world with sufficient demand to fuel economic growth; this would inevitably lead to what he calls an 'illiquidity problem', and which we now identify as the 'Triffin Dilemma'. This 'dilemma' still correctly describes the tension involved in stimulating global demand through the widespread circulation of a single national money. Because Triffin recognised the contradictions involved in such a 'national' solution to this 'world' problem, his own preferred solution was to internationalise the provision of world liquidity, which would in turn internationalise the transmission of global demand (Triffin 1960: 90-93). ${ }^{10}$ That this solution was never properly taken up should not blind us to its perceptive analysis of 'world money', which will have both international and domestic features because of the particular way global or world liquidity must be provided.

\footnotetext{
Footnote 6 (continued)

Lombardi and Malkin (2017) consider the inter-relationship between international and domestic factors, but focus on strategies of liberalisation rather than social policy.

${ }^{7}$ See, for example, Thimann (2008), who distinguishes analytically between an international versus a global role for currencies, yet collapses this distinction in his empirical investigation. The debate on the euro as an international currency is considered more fully in Germain and Schwartz (2014).

${ }^{8}$ None of these scholars employed the term 'world money' as far as I can tell, despite the title of one of Triffin's publications (1966). However, for the reasons discussed above I shall use it when discussing their work.

${ }^{9}$ In a fixed-rate regime, 'further increases in dollar balances cannot be relied upon to contribute substantially and indefinitely to the solution of the world illiquidity problem' (Triffin 1960: 63).

${ }^{10}$ Triffin's call to internationalise the provision of world liquidity was echoed during the 2008/2009 global financial crisis by the Governor of the People's Bank of China (PBoC), Zhou Xiaochuan, who called for a non-national form of international reserve asset. Mr. Zhou invoked Triffin's name directly in his 2009 call for world monetary reform (Chin 2014: 188; Drezner 2009: 39-40).
} 
The second claim to emphasise is the recognition that global demand can be transmitted though different channels. In the 1950s, Triffin focused on the accumulation of foreign dollar balances - which were the product of US corporations investing abroad alongside heavy American military expenditures - as the key mechanism driving the expansion of global liquidity. But financial intermediation, especially through New York banks and financial markets, also played a significant role in providing liquidity to the global economy. This is the contribution made by Kindleberger (1981), who outlines New York's role as a global financial centre that provides financial intermediation to the world by borrowing short and lending long on a global scale. Global demand, in other words, is not simply a function of the excess of imported goods and/or services a leading economy consumes, which transfer its currency and its purchasing power abroad. It can also be mediated through the creation and distribution of financial assets as capital exports (Kindleberger 1981: 28; see also Germain 1997). When Kindleberger first offered this insight (in the 1960s), America's balance of payments consisted of trade and current account surpluses but very large capital account deficits. The outflow of American foreign direct investment (FDI) and portfolio capital (along with foreign aid and substantial military spending abroad) drove increases in global monetary stocks, and this required intermediation via a globally oriented network of US-based financial institutions. Global financial intermediation is a critical channel through which demand from a leading economy to the world is distributed. In this sense, like Triffin, Kindleberger saw a connection between world liquidity provision (i.e. growth in monetary stocks) and global demand, but he emphasised the channels through which such demand flowed. ${ }^{11}$

The third claim to emphasise comes from Susan Strange, who built indirectly on the work of Triffin and Kindleberger to draw attention to the domestic consequences that arise when a national currency is used to fund increases in global monetary stocks, which in turn helps to drive global demand. Shortly before the demise of the fixed link between gold and the dollar, she noted that the American economy was particularly vulnerable to the effects of international monetary shocks because of the way in which the central position of its capital markets in the global economy amplified those disturbances. She pointed out that a top currency country (in my terms, the country issuing world money) was highly vulnerable to fluctuations in global demand (Strange 1971b: 226-27). ${ }^{12}$ The only way to boost liquidity and demand

\footnotetext{
11 Triffin and Kindleberger disagreed about how world liquidity could be provided. Triffin wanted to internationalise the provision of world liquidity via a new, non-national currency unit, and was influential in the creation of the Special Drawing Right at the IMF in the 1960s (Calleo and Strange 1984: 105-106). Kindleberger's preferred method to provide world liquidity was through financial intermediation, most importantly by supporting the establishment of private international capital markets (Kindleberger 1981: 25-30, 51-52 and 54-55).

12 Strange here ran against the prevailing intellectual currents in identifying the sensitivity of US financial markets to international disturbances. Because these markets channelled such large investments abroad, they were acutely responsive to changes in the distribution of the costs and benefits associated with them, whether at home or abroad. In my terms, this was an effect of the cohesiveness of the global political economy, which placed New York capital markets at the centre of the global financial system (Germain 1997, Chap. 3).
} 
in the global economy in a sustainable manner, she thought, was for a dominant economy eventually to run trade or current account deficits. However, Strange also recognised that these deficits would generate adjustment costs, primarily job losses among low and medium-skilled workers (from rising import competition), which would in turn lead to a political demand for welfare provision (Strange 1971b: 227). She further noted that these groups fared worse in the United States than in other Organization for Economic Co-operation and Development (OECD) countries. As was the case with Britain and sterling, she argued that the United States could only run the world's top currency successfully if it cushioned marginal or vulnerable domestic groups from the dislocations they would face. Dealing with the economic dislocations arising out of a susceptibility to monetary or financial disruption was for her the key political cost of running world money. ${ }^{13}$

In subsequent work Strange amplified this observation in two ways. On the one hand, she noted time and again that domestic welfare considerations in powerful states have important effects on the structure and organisation of the global political economy. Protectionism - which might be considered an indirect form of welfare provision - was in her view an integral element of the world's production structure, and she argued in the mid-1980s that world trade could co-exist easily and comfortably with stable and predictable levels of protectionism (Strange 1985: 236-37 and 255; see also Stopford and Strange 1991: 62). Protectionism here played the politically important role of cushioning vulnerable workers (who were also voters) in the United States. She also observed in her final publication that the failure of welfare provision to keep pace with the distributional deficiencies of global capitalism was part and parcel of what she derisively called the 'Westfailure' system (Strange 1999: 346-47).

On the other hand, over time she came to consider the domestic political and economic foundations of the United States to be at the same time foundational features of the broader global political economy. We can see this at work in her conception of structural power, which emanates outwards from the networks and bargains generated by the institutional arrangements of dominant states (Strange 1988: 39-42). She eventually came to identify the global political economy itself as a non-territorial or transnational American empire, which meant that welfare provision in America became in effect a world political problem precisely because its inadequacy made the American political system dysfunctional and prone to abrupt policy shifts when marginalised and vulnerable citizens became politically mobilised (Strange 1989). This was how, for Strange, domestic social peace in America could be considered a 'global' issue.

Triffin, Kindleberger and especially Strange lead us to, first, recognise the link between world money and its accumulation abroad as a source of growth in global demand; second, extend the means of providing global demand to include financial

\footnotetext{
13 This is the concluding argument of Sterling and British Policy, namely that by ceasing to support sterling as a quasi-world money British policymakers could finally concentrate on building the kind of society its people deserved, 'undistracted and undisturbed' by how to pay the costs required to run such a currency (Strange 1971a: 349).
} 
intermediation and the generation of financial assets; and third, connect the provision of global demand (and its fluctuation) to rising domestic adjustment costs for the provider of world money, and to the political need to ameliorate these costs in order to prevent social dislocation. My contribution to this framework is to consider more narrowly how these costs have been (at least partially) met through the development of welfare provision in Britain from 1870 to 1930, in America from 1950 to 2020 , and in China from 2000 to 2018 . Here I go beyond these early theorists to isolate and explore a specific domestic political arrangement that helps to enable a state to run world money.

It is important to stress again, however, that my framework does not dispute the importance of what many identify as the international foundations for currency internationalisation, viz., currency convertibility, financial markets capable of performing complex financial transactions, a sufficient volume of the currency in global circulation, and a state capable of negotiating the complex monetary and political arrangements that historically have constituted the international infrastructure of a global currency. But I suggest this literature also needs to recognise that a state which issues world money must also be able to negotiate the domestic adjustment costs associated with running such a currency. The basic claim advanced here is that such costs, which come from many different directions, need to be managed for social stability to be sustained. Direct welfare provision is not the only way of ameliorating such costs, as we will see below, but I suggest that it forms an important element of how the two states that have issued world money over the past two centuries were able to sustain this role politically.

\section{The political economy of world money: empirical connections}

What kinds of domestic costs can we associate with running world money? At one level, we need to recognise that these are part of the general range of costs connected to deep involvement in the global economy, since they arise out of the overall balance of a country's international economic transactions. Deep and sustained integration between economies leads to many kinds of imbalances, which in turn generate many kinds of adjustment costs, as recent studies have amply demonstrated (Autor et al. 2013). ${ }^{14}$ Parsing out that part connected to running a world money - or even just a run-of-the-mill international currency - is no easy matter. Helleiner (2017: 24 ), in a recent assessment of the costs and benefits of the global role of the US dollar, concludes that the exercise itself is fraught with ambiguity. This is another warning to be cautious in attributing causality to any of the connections which may be identified. I do not want to suggest in what follows that welfare states have been developed only by states which issue world money, much less that there is a direct

\footnotetext{
14 A more recent essay by these authors examines the trade-related costs of Chinese exports to America. They estimate that since 1990 over 2 million American workers have been displaced directly or indirectly by increased imports from China, and that their incomes have suffered despite an increase in transfer benefits (Autor et al. 2016).
} 
connection between the extent of welfare provision that a state develops and its issuance of world money. After all, states which have not issued world money have developed very extensive welfare provision - such as many small northern European states - while the current issuer of world money, the United States, on some measurements continues to provide very paltry welfare provision. Rather, I am exploring the utility and value of asking such questions in the first place, to deepen our understanding of the process of currency internationalisation.

Taking our lead from Strange, the first point we may make about this relationship is that it arises because of the consequences of economic dislocation produced by the kinds of balance of payments imbalances generated when a country's currency is used as world money. These are often considered as adjustment costs to international economic competition. On the one hand there are the dislocations that arise when a country runs a merchandise or current account deficit as its currency is drawn into global circulation for a significant period of time. Such deficits can cost jobs as imports of goods and/or services replace domestic production, so one adjustment cost is generated when states expend resources to provide income support, a jobs strategy and retraining programmes in response to such dislocations.

On the other hand there is a set of costs associated with strong demand for world money, which can place upward pressure on a currency's value as foreigners seek to acquire it. An appreciating currency erodes the competitiveness of exports and makes imports more attractive, thus reinforcing the first type of deficit. Demand for a currency can also stimulate the financial sector, which in turn might draw resources such as skilled labour to it, and grow its size relative to other sectors of the economy. One consequence might be an outsized financial sector that unbalances the growth dynamics across an entire economy, contributing in some way to increases in inequality among the general population as more wealth is concentrated in the financial sector (Chey 2012: 55; Helleiner 2017: 14-15; cf. Kindleberger 1981; Hager 2016). In any case, the principal point here is that the trade, current and capital account imbalances connected to issuing world money can generate dislocations of varying kinds, which then command resources from states in order to be addressed.

The chief rationale for benchmarking welfare provision as a domestic foundation of currency internationalisation is that it supports people in their efforts either to obtain the skills necessary to continue participating in the workforce, or to replace lost purchasing power in a manner that supports aggregate demand (and thus the capacity to consume imports). Of course, welfare provision is not the only way to support purchasing power - in Britain during the nineteenth century and America during the latter decades of the twentieth century, declining food prices and surging home prices accomplished much the same thing. ${ }^{15}$ But welfare spending is one of the clearest tools available to governments to combat job displacement and the erosion of purchasing power, and moreover in two of the three cases considered

15 The relationship between purchasing power and currency internationalisation is explored more fully in Germain and Schwartz (2017). 
here the expansion of welfare provision formed a central object of political contests waged through electoral systems. ${ }^{16}$

States have sought to ameliorate the adjustment costs due to economic competition and social dislocation in a number of ways. Some, like educational options to help prepare citizens for the world of work as well as to provide well-qualified workers for employers, are quite general in orientation, and have been a product of the universal history of the modern state. But when actual economic dislocation occurs, states have often developed a range of labour-market training initiatives and unemployment insurance to help workers transition to new employment opportunities. Together these policies directly prepare citizens for economic competition and cushion their standard of living when they encounter dislocation. States have also developed social security programmes to mitigate inequality and poverty. These programmes help to ensure that a basic standard of living is available to all citizens regardless of their own capacities, which has the additional benefit of upholding aggregate demand for the economy. And finally, states over time have developed healthcare systems to enhance their citizens' quality of life and to treat disease, which also helps to reduce poverty and inequality by redistributing their associated costs and enabling people to lead longer and more productive working lives. These are the kinds of policies that I track below as welfare provision, or what can also be identified more generally as social security.

There are four different budget items that can be used to measure welfare provision as I have defined it here: education and training expenditure (which develop labour-market skills); welfare and social security spending (which support purchasing power and mitigate inequality); public pension expenditures (which support the maintenance of purchasing power among an important segment of the population); and public spending on healthcare (which can reduce inequality and support the maintenance of living standards). Together these budget categories correspond to what historians of welfare provision identify as the welfare state, which developed to protect vulnerable people from want, provide critical services such as education and healthcare, and channel transfer payments to ameliorate poverty (Fraser 1984: xxii). Undertaking a comparison of these general expenditures across our cases allows for some important observations to be made about the political sustainability of issuing world money.

Below I measure each of these budget items not in absolute terms but in terms of the size of the government budget and economy. My measurements calculate the size of spending in relation to both denominators so that we can see how much of a proportion of the economy and government budget is spent on welfare provision. I include both local and central government spending in my calculations. It is the case that the way states report their spending in these areas differs from country

\footnotetext{
${ }^{16}$ It is important again to stress that I am not making a claim that states expand welfare provision because they issue world money. As the literature on welfare systems makes clear, their development has responded almost entirely to domestic factors. More modestly, I am simply seeking to establish a connection (without yet implying causation) in order to make the case that asking slightly different kinds of questions about currency internationalisation can shed further light on this phenomenon.
} 
to country, and China's data presentation underwent a significant change in 2007, which compromises how we may compare its data on either side of this date. For this reason I present Chinese data from 2000 to 2018 with an inflection point in 2007.

I noted above that the modern universe of cases where states have issued world money is tiny, currently it comprises two cases. Comparing Britain and the US on many aspects of issuing world money raises significant questions about the generalisability of any results, and including China in our comparison further complicates this effort. Yet, I believe there is a compelling case to be made for the utility of this comparison. First, they are the only historical precedents we have, so however different they may be, such a comparison provides some level of utility to consider subsequent cases. Beyond this, the broader literature on currency internationalisation proceeds on the assumption that these cases inform each other, and that China in particular has digested at least some of the lessons of the American experience (Chin 2014: 187-92; Cohen 2019: 216-21). And finally, the idea of a currency internationalisation lifecycle (Chey 2012; Cohen 2019) suggests that despite the temporal disjuncture at work across the three cases there is enough commonality to proceed with a measured comparison. But I shall return to the limitations of our comparison in the conclusion.

\section{Britain 1870-1930}

The high point of sterling as world money is generally agreed to be from the final quarter of the nineteenth century through to the onset of World War I; this is the period in which the international gold standard became highly institutionalised. After the disruption of war, sterling returned to its pre-eminent position as world money during the 1920s, but was devalued in 1931 and never regained this status afterwards (Strange 1971a; Germain 1997; Langley 2002). I measure British spending on welfare provision from 1870 partly because this period corresponds with sterling's consolidation as world money, and partly also because government spending prior to 1870 in the areas I am measuring was minimal. ${ }^{17}$ This qualifies my observations about the connection between welfare and world money, and I reflect on these below.

In 1870, British government spending comprised just over 9\% of British GDP. Government spending on healthcare amounted to $0.09 \%$ of GDP, while that on education stood at $0.15 \% .{ }^{18}$ Slightly more was devoted to welfare, while pensions and unemployment insurance were not yet on the horizon. Contrast this with spending in

\footnotetext{
$\overline{17}$ Government spending in Britain prior to 1870 is dominated by military expenditures and payments on the national debt. In 1850, for example, total social spending took up less than $1 \%$ of the budget, and this barely doubled to about $2 \%$ in 1860 . All data taken from UKPublicSpending.co.uk (last accessed on 6 March, 2020).

18 It should be noted that full public funding for any category of welfare provision did not commence until the twentieth century, with Liberal governments beginning to fund education and pensions just prior to World War I, and a Labour government setting up the National Health Service in 1948.
} 
1930, just before Britain abandoned the gold standard. Total government spending had almost tripled to about $30 \%$ of GDP, spending on healthcare as a proportion of GDP had increased ten-fold, while education took more than twenty times its share as a proportion of GDP in 1870. Direct welfare spending had increased just under four-fold, while pension spending - which only started in 1909 - now represented a claim on British GDP of $1.22 \%$. Overall, if we consider these categories together to measure welfare spending as a whole, the British state increased its social spending from just over $10 \%$ of its total expenditures in 1870 to $26.73 \%$ in 1930 . Table 1 details spending in these categories over this period.

What does this data tell us about the relationship between welfare provision and the capacity of a state to issue world money? The first point is that we are entitled to ask about such a relationship, given how much state spending increased during this period. If we go back to 1850 , for example, when the era of sterling's world preeminence was just getting underway, of our four categories of welfare provision only education received any direct state spending, and this comprised less than $1 \%$ of total government spending. Sterling's heyday as world money is usually associated with the period of the international gold standard, which reached its Zenith between about 1870 and World War I, and this period saw exponential growth in spending on healthcare and education and a doubling of direct welfare spending as a percentage of British GDP. Even more telling, during the 1920s, as Britain laboured to restore the gold standard and re-establish sterling as world money, total government spending doubled and every category of social security except pensions increased significantly. Sterling's return to gold is often linked to the poor performance of the British economy during the 1920s (e.g. Eichengreen 1992: 187-90), so it would seem a logical step to extend consideration of this correlation to the role of sterling as world money during this decade, even if the extant literature on the welfare state has not yet done this.

But the second point to draw from this data is that any relationship between welfare and world money is bound to be complicated. For example, we need to note that sterling's role as world money began before any meaningful spending on welfare started. And once the British state began to devote resources to welfare expenditure, the principal drivers of this spending were a growing and sustained societal reaction against poverty, illness and inequality (Fraser 1984; Harris 2004: 23-25; Gilbert 1970: 2-5; cf. Esping-Andersen 1990: 1-2). These drivers were also at work across Europe during the latter decades of the nineteenth century: social insurance and state pensions, for example, were begun in Germany under Bismarck, and partially drew on France's earlier experimentation (Esping-Andersen 1990: 40). ${ }^{19}$ As well, World War I saw state spending in Britain and other belligerents spike to over $50 \%$ of GDP, and the exact place of welfare spending within this mix requires further research to untangle. It is also the case that all categories of welfare provision grew over the entire twentieth century: by 1970 in Britain they took up $45 \%$ of government

\footnotetext{
19 Here again however there is an interesting link to consider between welfare and world money, as France, Germany and Britain had the most highly internationalised currencies of this period, even if sterling by most accounts stood leagues above the French franc and German goldmark (Feis 1930/1964).
} 
Table 1 British government spending on social support 1870-1930 (select years)

\begin{tabular}{llcllll}
\hline & $\begin{array}{l}\text { Government } \\
\text { budget \% of } \\
\text { GDP }\end{array}$ & $\begin{array}{l}\text { Health } \% \\
\text { of GDP }\end{array}$ & $\begin{array}{l}\text { Welfare \% } \\
\text { of GDP }\end{array}$ & $\begin{array}{l}\text { Education } \\
\% \text { of GDP }\end{array}$ & $\begin{array}{l}\text { Pensions \% } \\
\text { of GDP }\end{array}$ & $\begin{array}{l}\text { Social spending \% of } \\
\text { total government spend- } \\
\text { ing }\end{array}$ \\
\hline 1870 & 9.16 & 0.09 & .68 & .15 & 0 & 10.1 \\
1880 & 11.13 & .15 & .57 & .60 & 0 & 11.58 \\
1890 & 10.43 & .13 & .49 & .74 & 0 & 13.03 \\
1900 & 14.06 & .30 & .57 & 1.36 & 0 & 15.85 \\
1910 & 15.95 & .43 & 1.00 & 2.46 & .04 & 24.58 \\
$1920^{\mathrm{a}}$ & 33.22 & .42 & .81 & 1.84 & 1.68 & 14.30 \\
1930 & 29.38 & 1.01 & 2.30 & 3.33 & 1.22 & 26.73 \\
\hline
\end{tabular}

Source UKPublicSpending.co.uk

(https://www.ukpublicspending.co.uk/year_spending_2020U Kmt_17mc1n\#ukgs302, accessed February 26th 2020)

${ }^{\text {a }}$ The proportions of public spending in 1920 continued to reflect wartime priorities, with defence absorbing just over $35 \%$ of the government budget. In absolute terms, however, the amounts spent on social protection measures continued to climb steadily

spending (by which time sterling had ceased to act as world money); by 1990 they took up 54\%; and they are expected to take nearly $64 \%$ of government spending in 2020 , or about $25 \%$ of Britain's GDP. ${ }^{20}$ Taken in the round, issuing world money is clearly only one of several factors in this complex mix, but neither is it one we should ignore. I would claim here that the British case warrants further research to examine the complex relationship between welfare provision and how states which issue world money respond to the adjustment costs that are at least partly associated with this phenomenon.

\section{The United States 1950-202021}

In 1950, on the eve of the Korean War, total government spending in the US (federal and state governments combined) was $23.45 \%$ of American GDP (or about 20\% less than total government spending in Britain in 1930). Of this amount, less than $1 \%$ of GDP went towards public healthcare, just under $2 \%$ of GDP went towards welfare provision, while $3.2 \%$ of GDP went towards education and $0.47 \%$ provided for pensions. Interestingly, these numbers are not dissimilar to Britain's spending in 1880, except that they comprise a much larger share of the government's overall budget (at nearly $28 \%$ for all social support spending). By 1970, as the efforts of the

\footnotetext{
20 All data taken from UKPublicSpending.co.uk (last accessed on 6 March, 2020).

21 The US dollar, while it did have a limited international footprint between the wars, was in reality a regional currency. It is probably more correct to note that there was no world money during this time, as the world economy was heavily regionalised, including the circulation of currencies around dollar, sterling and gold blocs (Germain 1997: 58-72). I could have presented data here from 1945, except that American government spending for several years after the war was disproportionally affected by wartime priorities, much like British spending in 1920. Starting with spending in 1950, therefore, seems appropriate.
} 
Nixon administration to support the Bretton Woods pegged exchange rate system neared exhaustion, total public spending at the federal and state level had climbed to nearly $30 \%$ of GDP, with the share devoted to healthcare more than doubling. Welfare spending as a percentage of GDP had flatlined, while education's share had increased by over half to $5.26 \%$ of GDP. Government spending on pensions had nearly quintupled to almost $3 \%$ of GDP, while total social spending now accounted for over $40 \%$ of government expenditure. If we take 1930 as a relatively comparable benchmark with Britain in terms of the lifecycle of an international currency, while the proportion of American spending on welfare in terms of GDP ranked below Britain's spending across all categories, the percentage of the US government's budget devoted to social support of all kinds was one third greater. This observation provides an intriguing clue as to why the devaluation of the dollar in 1971 did not have the same effect on the global financial system (and economy) as did Britain's devaluation in 1931: the US government was better positioned to provide domestic support for the continued global role of the dollar than was Britain with respect to sterling. ${ }^{22}$

By 2010, total government expenditure in the US accounted for nearly $42 \%$ of GDP, reflecting the federal government's spending response to the 2008 financial crisis. Healthcare now accounted for $7.39 \%$ of GDP, while spending on the other categories I am tracking grew as a proportion of GDP. Total spending on all welfare and social security spending comprised just over $61 \%$ of the government's budget. Estimates of similar spending for 2020 show continuing increases for government spending on healthcare and pensions but a reduction in welfare and education spending, which is a consequence of both the time-limited increases built into the Obama administration's response to the financial crisis as well as the retrenchments engineered by the Trump administration after $2016 .{ }^{23}$ Over the seven decades from 1950 , however, government spending for social support as a percentage of all public expenditures has climbed over $20 \%$, going from nearly $28 \%$ of total government spending in 1950 to almost $41 \%$ in 1970 to nearly $62 \%$ in 2020 . These data are presented in Table 2.

How does this data fit into the framework I am developing? The first point to note is that while American support for direct welfare spending remains low by richworld standards, it has consistently outpaced British spending throughout its entire currency internationalisation lifecycle. American spending on social security as a percentage of its budget in 1950 was already as high as Britain's was in 1930, and it more than doubled over the period to 2020, with every category except direct welfare support growing markedly. As America's economy has become progressively enmeshed in the economic transactions of the world economy, its welfare provision, broadly construed, has increased.

\footnotetext{
22 Space limitations prevent me from pursuing this below, but this observation supports Seabrooke's contention (2006: 2) that state support for low income groups provides a critical part of the infrastructure of legitimacy required to exercise international financial power.

23 Please note that these data do not anticipate any additional funding for COVID-19 related expenditures, which were not available during the final preparations of this manuscript.
} 
At the same time, it is interesting that from about 1950 until the mid-1960s, most of the spending I am tracking here grew modestly, except for pensions (a legacy of military service in World War II and the Korean War). Economic growth alone in the US did not generate sufficient global demand to power growth in the world economy, partly because it was coupled with America's strong export performance which generated large trade and current account surpluses (thereby depressing global demand). America's contribution to global growth came instead from the capital account (comprised of military spending abroad, foreign aid such as the Marshall Plan, and FDI). Robert Triffin was not the only one to worry about a dollar shortage on a world scale, and it is an open question as to how much the flatlining of America's welfare provision contributed to this problem. In any case, it is further evidence of how the organisation of the domestic political economy of the world's most important economy can generate global consequences.

From the mid-1960s on, however, strong domestic economic growth became coupled with expanded healthcare and pensions, powering significant growth in American consumers' purchasing power that was finally able to help generate global demand (and a corresponding trade deficit). Today there is much concern over the cost of entitlement programmes in the United States such as Social Security, Medicare and Medicaid, but these programmes (among others) support the maintenance of incomes and thus purchasing power among America's middle classes. We can also consider education spending to work in this direction as well, to the extent that it provides American workers with the skills which they require to adapt to economic change. ${ }^{24}$ In this context, therefore, the growth of welfare and social security spending in the United States should be considered a significant part of post-war American consumer demand. Accordingly, further exploration of the possibility that it played some kind of role in maintaining the status of the dollar as world money seems warranted. ${ }^{25}$

It is important to consider, as well, that welfare provision in the United States - on some measures still among the least generous of rich countries - is not only composed of direct government expenditures. It is augmented considerably by what Christopher Howard calls the 'hidden' welfare state, which is constituted by policies, such as mortgage interest rate tax relief, that are hidden from view because they are delivered as deductions and credits rather than direct expenditures (Howard 1997; see also Block 2008). When these credits are considered alongside the expenditures I am tracking here, the footprint of America's welfare state grows, most importantly by supporting the purchasing power of the middle class.

\footnotetext{
${ }^{24}$ In the most recent PISA (Programme for International Student Assessment) rankings, conducted in 2018, American students ranked highly in science and reading, but just below the OECD median in mathematics. Source: https://www.oecd.org/pisa/PISA-results_ENGLISH.png (last accessed on 2 April, 2020).

25 As with the growth of the welfare state in Britain, the literature on American welfare provision highlights predominantly domestic causes such as the concern to address poverty, illness, inequality, and inclusion, especially as framed by the Great Depression and the civil rights movement. See, for example, Trattner (1989) and Noble (1997).
} 
Table 2 American federal and state spending on social support 1950-2020 (select years)

\begin{tabular}{lllllll}
\hline & $\begin{array}{l}\text { Government } \\
\text { budget \% of } \\
\text { GDP }\end{array}$ & $\begin{array}{l}\text { Health } \\
\% \text { of } \\
\text { GDP }\end{array}$ & $\begin{array}{l}\text { Welfare } \\
\% \text { of } \\
\text { GDP }\end{array}$ & $\begin{array}{l}\text { Education } \\
\% \text { of GDP }\end{array}$ & $\begin{array}{l}\text { Pensions } \\
\% \text { of } \\
\text { GDP }\end{array}$ & $\begin{array}{l}\text { Social spending \% of } \\
\text { total government spend- } \\
\text { ing }\end{array}$ \\
\hline 1950 & 23.45 & 0.90 & 1.90 & 3.20 & 0.47 & 27.60 \\
1960 & 27.89 & 0.96 & 1.59 & 3.58 & 2.54 & 31.19 \\
1970 & 30.00 & 2.27 & 1.74 & 5.26 & 2.98 & 40.89 \\
1980 & 32.91 & 3.48 & 2.92 & 5.32 & 5.19 & 51.40 \\
1990 & 34.93 & 4.31 & 2.20 & 5.11 & 5.21 & 48.19 \\
2000 & 31.66 & 4.96 & 2.41 & 5.77 & 5.55 & 57.01 \\
2010 & 41.91 & 7.39 & 4.47 & 6.14 & 6.49 & 61.63 \\
2020 Estimate & 36.45 & 8.12 & 2.06 & 5.52 & 6.82 & 61.78 \\
\hline
\end{tabular}

Source USGovernmentSpending.com (https://www.usgovernmentspending.com/year_spending_2020U Sbt_20bs2n\#usgs302, accessed February 28th 2020)

Are there other features of American public policy that support American purchasing power in a manner analogous to welfare provision and social security? One policy that should be considered in this light is American government support for home ownership. Seabrooke (2006) and Schwartz (2009) for example highlight how government support for home ownership over the entire post-war period increased the wealth effect for middle-class workers and enabled them to cope with the very real adjustment costs associated with the growing entanglements of the American economy in the world economy. The point I wish to stress here is that we can consider American housing policy as a form of indirect welfare provision, much as Strange (1985) considered protectionism to be an indirect form of welfare provision. The high rate of home ownership, together with financial innovation in the US mortgage-finance system, boosted the wealth of middle class Americans throughout the post-1945 period. In the early years (circa 1950-1980), home ownership provided above average wealth effects because home prices rose slightly faster than inflation and mortgage debt, while after the early-1980s Volcker interest-rate shock, the combination of falling interest rates and financial innovation enabled home-owners to access cheap credit to bolster their incomes. As a result, middle class Americans were able to act as the engine of global demand, consuming a significant amount of new European and Asian manufacturing output over this entire period. Although it is not uncontentious, I would suggest that taken together the combination of American government housing policy, the hidden welfare state and direct welfare provision and social security were the principal mechanisms by which American workers - and especially those who are most vulnerable - were cushioned from the costs of America's growing involvement in the world economy.

Examining the data on American welfare provision provides further evidence that domestic government spending plays some role in ameliorating the costs of issuing world money. That such expenditures have increased over the entire period of dollar dominance in the world economy suggests that the American state continues to ameliorate at least some of the sharpest domestic adjustment costs that are connected to 
the dollar's role as world money. Welfare provision in America comprises a welter of policies, and includes the categories I am tracking as well as the hidden welfare state and government housing policy, which has been organised around government sponsored entities and supported by mortgage interest rate relief over the entire post1945 period. We should consider these policies in combination to be part of the reason that the American economy (read here as the American consumer) has been able to power global demand over the past decades. Once again, there is a prima facie case for including welfare spending among the domestic foundations that allow a country to issue world money, even if it may not be the single most important factor at work.

\section{China 2000-2018}

China began to open up to the global economy in 1979, and has modernised its state institutions over the past four decades. Chinese data are not as complete as in our other two cases, and in 2007 there was a major overhaul of how many of these statistics were gathered and formulated so that comparisons between pre- and post-2007 must be treated with caution. Nevertheless, there is enough here to begin a comparison with the British and American cases. The first point to note is that China's government spending on welfare provision today resembles in most respects the spending levels for late-nineteenth century Britain, except that China's government footprint is larger than was liberal Britain's at the time. Indeed, after its economic opening, government spending in China as a proportion of GDP plunged by about $40 \%$ between 1980 and 2000 before recovering. ${ }^{26}$ This is significant, because it means that the Chinese state directs fewer resources to meeting the social security needs (and by implication adjustment costs) of its citizens than does either Britain or the United States today. Data for government spending by China's central and provincial authorities are presented in Table 3.

How does this data fit into the framework I am developing? One is immediately struck by the low level of government spending on healthcare, welfare and employment support, and education. Already beginning from a lower threshold in 2000, by 2018 these accounted for about $15 \%$ of GDP, whereas in the US this spending currently runs at nearly $23 \%$ of GDP, or about $50 \%$ higher. If we consider the US at a similar point in its currency internationalisation cycle, however, what Cohen (2019) would consider the 'youth' stage (approximately 1950), American government spending on total social support only clocked in at $6.5 \%$ of GDP, while in the British case (approximately 1870), such spending took up less than 1\% of GDP (which increased to nearly $7 \%$ of GDP by 1930). One conclusion to draw from such a comparison is that in terms of the domestic political foundations for supporting a world money, China is no more than at the beginning of its cycle, with perhaps decades

\footnotetext{
26 Total government spending in China declined dramatically from just under $28 \%$ of GDP in 1980 to a nadir of $11 \%$ in 1996, before beginning its steady climb to where it is now. Data from National Bureau of Statistics of China, available at http://data.stats.gov.cn/english/easyquery.htm?cn=C01 (last accessed on 10 February, 2020).
} 
of development ahead of it. Indeed, Leung and Xu (2015: 5-6) suggest that China, which they believe is at a critical turning point in the development of its welfare system, must significantly expand and modernise its provision of social security to achieve its goal of becoming a prosperous and harmonious society. Figures 1 and 2 portray the welfare provision spending of Britain, America and China in a comparative perspective.

One implication we may therefore draw from China's current level of spending is that, like Britain and America before it, there is much room for growth in terms of public spending in general and on welfare provision in particular. The secular trend for such spending in countries that issue world money is to increase markedly over time. China could also follow the American path, developing either a 'hidden' welfare state and/or an expansive housing market, supported by generous government incentives alongside a propensity for financial innovation that unlocks low-cost credit to home-owners. At the current moment, however, neither pathway appears likely, which produces a genuine puzzle: how might China better develop its welfare provision to cushion its citizens from the effects which historically have accompanied the issuance of world money? For example, as the Communist Party prepares to guide China towards a full-fledged market economy in order to engineer much higher levels of domestic consumption, how precisely will it fund and manage the adjustment costs connected with erasing its steel and other production overcapacities?

Two reasons suggest caution with respect to China's chances of success. First, state-owned enterprises (SOEs) possess varying degrees of monopoly power in China's economy, allowing them to capture profits systematically and use these to reinforce their entrenched advantages, which undermine efforts to increase mass consumption (Hung 2013: 1355). These privileges are unlikely to be unwound easily. Second, China's largely repressed financial system reinforces the position of SOEs by channelling household savings towards them (Bowles and Wang 2013; Gruin 2013; Yu 2015: 47; Aizenman 2015: 453). Such official support for SOEs acts as a detriment to the development of a welfare system by amplifying the pressure on Chinese households to self-insure by saving large proportions of their income. They are 'target savers', who increase their savings in response to low returns; but paradoxically, such saving provides the banking system with even more funds to lend to SOEs. Target saving drastically reduces Chinese households' ability to consume, and by implication their ability to import (Pettis 2014). China's political economy is thus structurally biased toward the creation of overcapacity and excess exports, and many suggest that this will not be easily unwound (McNally 2015; Otero-Iglesias and Vermeiren 2015; Sohn 2015). To the extent that this structure continues to privilege export-oriented firms (many of whom are SOEs), redirecting these resources towards welfare provision to citizens remains a daunting task (Germain and Schwartz 2017). ${ }^{27}$

\footnotetext{
27 China's domestic consumption rate has been stuck at $60-70 \%$ of rich country norms for decades. Whereas in 2000 domestic consumption represented between $80 \%$ and nearly $84 \%$ of American and British GDP respectively, in China this figure stood at just over $63 \%$. But by 2015 , with British domestic consumption continuing to clock in at $84 \%$ of GDP and American consumption ticking up to $82 \%$ of GDP, China's consumption rate had plunged to just over $52 \%$. This decline has been led by house-
} 
Table 3 China central and local government spending on social support 2000-2018 (select years)

\begin{tabular}{lllllll}
\hline & $\begin{array}{l}\text { Government } \\
\text { budget \% of } \\
\text { GDP }\end{array}$ & $\begin{array}{l}\text { Health \% } \\
\text { of GDP }\end{array}$ & $\begin{array}{l}\text { Welfare } \\
\text { \% of } \\
\text { GDP }\end{array}$ & $\begin{array}{l}\text { Education } \\
\text { \% of GDP }\end{array}$ & $\begin{array}{l}\text { Pensions (Social } \\
\text { Insurance Fund) \% } \\
\text { of GDP }\end{array}$ & $\begin{array}{l}\text { Social spending \% } \\
\text { of total government } \\
\text { spending }\end{array}$ \\
\hline 2000 & 18.20 & 0.71 & 1.51 & 2.53 & 2.30 & 39.20 \\
2003 & 20.83 & 0.81 & 1.93 & 2.80 & 2.89 & 40.52 \\
2006 & 21.32 & 0.81 & 1.99 & 2.89 & 2.90 & 40.31 \\
2009 & 25.35 & 1.15 & 2.18 & 2.99 & 3.46 & 38.59 \\
2012 & 27.38 & 1.35 & 2.34 & 3.94 & 4.00 & 42.46 \\
2015 & 30.74 & 1.74 & 2.76 & 3.81 & 5.21 & 43.97 \\
2018 & 30.92 & 1.79 & 2.94 & 3.50 & 6.89 & 48.61 \\
\hline
\end{tabular}

Please note that I have combined here pre- and post-2007 data, even though these are not entirely comparable. However, they do reflect the trendline for social security expenditures, even if these are calculated differently during these two periods. For the purposes of comparison, total government spending here includes expenditures related to the Social Insurance Fund, which is a government mandated fund designed to provide social support but not counted as part of national government expenditures. I have combined the expenditures in this fund related to basic pensions, unemployment insurance and medical insurance

Source China Statistical Yearbook National Bureau of Statistics (http://data.stats.gov.cn/english/easyq uery.htm?cn=C01, accessed February 10th 2020)

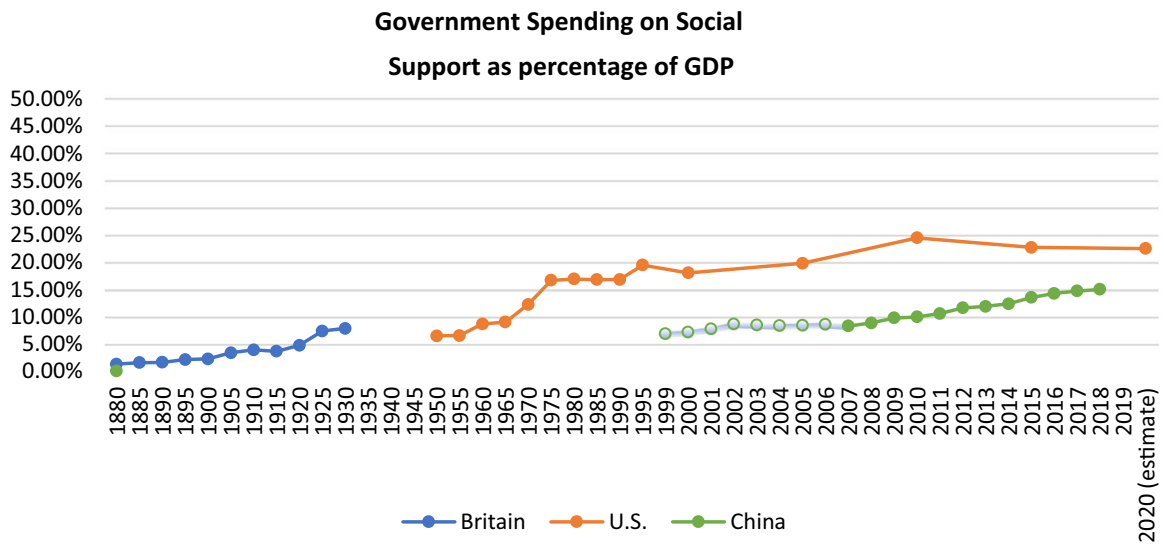

Fig. 1 Britain, USA and China government spending on social support as percentage of GDP 1880-2020 (select years)

When we consider the combination of low welfare provision by the state in China alongside the structural bias of its economy towards generating significant current

Footnote 27 (continued)

hold spending, which plummeted from 53\% of China's GDP in 1970 to just 35\% of GDP in 2010. Even in 2015, after several years of efforts to rebalance the engine of Chinese economic growth, household spending still represented only $38 \%$ of China's GDP. Data available online from World Bank at https:// data.worldbank.org/indicator/NE.CON.TOTL.ZS (last accessed on 12 February, 2019). 
Government Spending on Social

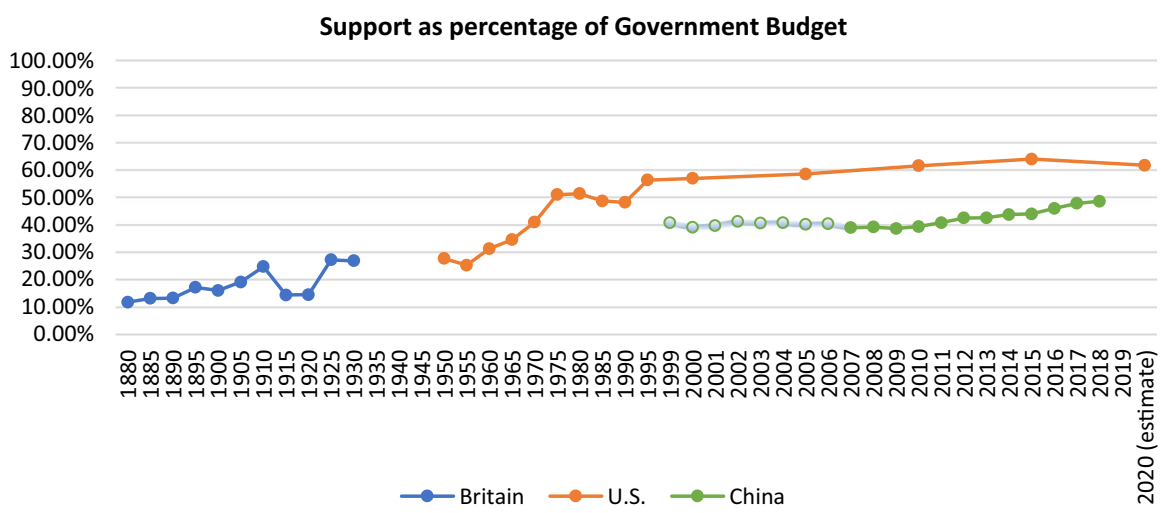

Fig. 2 Britain, USA and China government spending on social support as percentage of government budget 1880-2020 (select years)

account exports, and then include also its repressed financial system (which retards financial intermediation and innovation) together with the immense privileges currently enjoyed by SOEs and other entities with strong connections to the CCP, it is difficult to map out a route to successful RMB internationalisation that includes a strong domestic welfare system as a significant domestic foundation. It is not just that, as the current literature emphasises, sustainable financial liberalisation faces many challenges. It is also that the state in China does not yet have anywhere near the capacity to meet the adjustment costs that will be generated by modernisation. China is not only in an early stage of its currency internationalisation cycle; it is unclear whether it possesses the capabilities that previous issuers of world money have had at a similar stage in their cycles. It resembles more the Britain of the 1920s than the America of the 1970s.

\section{World money and the welfare state: insights and further research questions}

If we include the provision of welfare and social security as an important domestic foundation of the political economy of world money, what insights does this generate for further research? I began by noting that world money adds to global demand by circulating outside its issuing state's borders. The resulting balance of payments imbalances necessarily imposes costs on those domestic groups that lose jobs and income, which in turn generates pressure to accommodate such costs through some combination of polices. This imbalance of course also creates jobs and augments incomes for those connected to the global circulation of world money, but my point here is that our understanding of this phenomenon is deepened if we pay attention to how it is that the costs (rather than the benefits) are addressed (cf. Chey 2012: 54-58). This is where a consideration of the extent and efficiency of welfare 
provision adds value to our understanding of currency internationalisation. It opens an entirely novel way of thinking about the efforts economically powerful states undertake to internationalise their currencies. Most importantly, it suggests that developing a modern welfare state is an important feature of the drive to internationalise a currency. While this may not be the only way in which vulnerable groups may be cushioned from the manifold effects of balance of payments imbalances, it is certainly an important one. Although my argument at this stage must remain preliminary, I believe it is promising enough to warrant further investigation into such connections. We need more research to deepen our understanding of the connections between these pressures and their associated policy responses to advance our understanding of the political economy of currency internationalisation.

This conclusion complements the results of much current research on RMB internationalisation, which suggests that the RMB is not yet a genuine world money (Chey 2013; Cohen and Benney 2014; Eichengreen et al. 2018; McDowell and Steinberg 2017; Cohen 2019). It provides further evidence to help understand why the RMB is not yet capable of mounting a full-scale challenge to the global role of the US dollar. My argument also reinforces those who emphasise the multi-dimensional attributes which continue to promote dollar hegemony (e.g. Norrlof 2014; Stokes 2014; Cohen 2015; Hager 2017), by extending the analysis to consider an under-studied feature of the domestic foundations of world money. One value-added element of my framework is that it adds further domestic analytical depth to how we assess potential challenges to a foundational element of international monetary order.

For example, such analytical depth could add considerably to how we understand currency internationalisation by adding an important benchmark to what Chey (2012) and Cohen (2019) identify as the 'life cycle' of international currencies, or world money in my terminology. Both raise the idea of a life cycle as one aspect of currency internationalisation, but without specifying how such a life cycle might unfold in domestic terms. ${ }^{28}$ If we add benchmarks measuring welfare state provision to the more common ones associated with how currencies are used internationally, we would be in a position to assess more completely the domestic capacity of a state to sustain the international use of its currency. The key point here is to recognise that a currency not only requires others to use it to become genuinely 'international' (Chey 2015), it also calls for support to be provided to certain domestic constituencies in order for such international use to become sustainable on the home front.

An important qualification to this insight, however, remains the comparability of the three cases examined here. They are of course different in many ways, including in terms of their political regimes, the organisation of their economies and financial

\footnotetext{
${ }^{28}$ While Chey (2012: 57) raises, but does not explore, the point that the costs and benefits of issuing an international currency change over time, Cohen (2019: Chaps. 4-6) investigates in some depth the array of policy choices open to an international currency's issuing state in the different phases of its life cycle, which he characterises as youth, maturity and decline. The stage of the life cycle is important because it presents states with alternative sets of policy options as they consider whether and to what extent to pursue currency internationalisation. Although Cohen does not do so, I would argue that adding such a temporal element to his taxonomy has the potential to deepen its analytical purchase.
} 
systems, and in the ways in which their economies are enmeshed in the world economy. As well, the length of the temporal horizon itself presents a rather unique comparability challenge. At the same time, as I suggested above, the universe of cases of states issuing world money is tiny, so in effect we have no choice but to search among the histories of our cases for points of comparability. Welfare and social security spending, I believe, provides one such axis of comparison, precisely because it affords us a vantage point from which to consider the political sustainability of issuing world money. Most importantly, it points to the continued importance of domestic political economy for our understanding of how the global political economy itself is organised. We should always ask who pays the costs of upholding political and economic institutions and arrangements, wherever those may fall, and the question of who issues world money is no exception.

This last point may be extended to suggest that we need to pay closer attention to how we understand the relationship between the political economy of powerful states and the broader organisation of the global political economy. I noted earlier that this was at the root of Susan Strange's counter-intuitive claim that America's under-developed welfare state was in fact a 'global' problem, and it led her eventually to consider the global political economy as a non-territorial American empire (Strange 1971, 1988, 1989). Indeed, much of her later work was preoccupied with the many links between domestic American politics and international monetary order, and the data presented here provide further evidence for the salience of these linkages. Others, too, have explored different aspects of these links, all of which suggest that there remains a fundamental relationship between domestic and global political economy. ${ }^{29}$ As Herman Mark Schwartz and I have noted elsewhere, given the enduring nature of the structural advantages supporting the continued use of the dollar as world money, it is American domestic politics that are critical to the global future of the dollar, rather than the individual strength of any potential challenger currency (Germain and Schwartz 2014, 2017). Harry Truman recognised all too well back in the early 1950 s that the buck really does stop, if not in the Oval Office itself, then somewhere between Washington and New York. For now, and into the immediate future (much less for better or worse), we would not be wrong to suggest that world money continues to be made in the USA.

Acknowledgements I wish to acknowledge the detailed comments and criticisms provided by the reviewers of this essay, and the support from the editors for helping to guide me through the revisions. This essay is part of a larger, collaborative research project conducted over the past several years with Herman Mark Schwartz on the question of currency internationalisation, and I thank him for his unstinting support, fulsome dialogue and constant encouragement. I would like to acknowledge Xeuqian Liang and Yili Zhou and thank them for their research assistance; they collected and organised the data used to track welfare payments across the UK, USA and China. And I would like to thank Darrin Antler for his help with assembling and exploring the comparative literature on the development of welfare benefits. This research was supported financially by Carleton University and the Faculty of Public Affairs, the

\footnotetext{
${ }^{29}$ See, for example, Seabrooke (2006), Langley (2008), Schwartz (2009) and Angrik (2018). These works all heed Robert Cox's seminal injunction that 'academic conventions divide the seamless web of the real social world into separate spheres, each with its own theorizing... It is wise to bear in mind that such a conventional cutting up of reality is at best a convenience of the mind' (Cox 1981: 126).
} 
Mitacs Global Research Internship Programme, and the Social Science and Humanities Research Council of Canada. Early versions were presented at the 2016 'Intersections of Finance and Society' Conference at City University London, the 2017 Hallsworth Conference on 'China and the Changing Global Order' at the University of Manchester, the University of Birmingham, and the 2018 Annual Conference of the International Studies Association. The claims and arguments in this essay have been strengthened by comments received from participants at those presentations, as well as from Greg Chin, Iain Hardie, Eric Helleiner, Alban Mathieu, Carla Norrlof, Juanamaria Vazquez and especially Herman Mark Schwartz. I am however solely responsible for all errors and omissions.

\section{References}

Aizenman, Joshua. (2015) 'Internationalization of the RMB, Capital Market Openness, and Financial Reforms in China', Pacific Economic Review 20(3): 444-60.

Andrews, David M., ed. (2008) Orderly Change: international monetary relations since Bretton Woods, Ithaca: Cornell University Press.

Angrik, Stefan. (2018) 'Structural Conditions for Currency Internationalization: international finance and the survival constraint', Review of International Political Economy 25(5): 699-726.

Autor, David., David Dorn and Gordon Hanson (2016) 'The China Shock: learning from labor market adjustment to large changes in trade', National Bureau of Economic Research Working Essay 21906, January 2016, Cambridge: National Bureau of Economic Research, available at http://www.nber. org/essays/w21906 (last accessed on 24 June, 2016).

Autor, David., David Dorn and Gordon Hanson. (2013) 'The China Syndrome: local labor market effects of import competition in the United States', American Economic Review 103(6): 2121-68.

Block, Fred. (2008) 'Swimming Against the Current: the rise of a hidden developmental state in the United States', Politics and Society 36(2): 169-206.

Bowles, Paul and Baotai Wang. (2013) 'Renminbi Internationalization: a journey to where?', Development and Change 44(6): 1365-85.

Braudel, Fernand. (1979/1984) Civilization and Capitalism, $15^{\text {th }}-18^{\text {th }}$ Centuries: Volume 3, The Perspective of the World, trans. Siân Reynolds, London: Fontana Press.

Calleo, David and Susan Strange. (1984) 'Money and World Politics', in Susan Strange, ed., Pathways to International Political Economy, 91-125, London: George Allen and Unwin.

Chey, Hyoung-kyu. (2015) 'Renmimbi in Ordinary Economies: a demand-side study of currency internationalization', China in the World Economy 23(3): 1-21.

Chey, Hyoung-kyu. (2013) 'Can the Renminbi Rise as a Global Currency? The Political Economy of Currency Internationalization', Asian Survey 53(2): 348-68.

Chey, Hyoung-kyu. (2012) 'Theories of International Currencies and the Future of the World Monetary Order', International Studies Review 14(1): 51-77.

Chin, Gregory. (2014) 'China's Rising Monetary Power', in Eric Helleiner and Jonathan Kirshner, eds, The Great Wall of Money, 184-212, Ithaca: Cornell University Press.

Cohen, Benjamin J. (2019) Currency Statecraft: monetary rivalry and geopolitical ambition, Chicago: University of Chicago Press.

Cohen, Benjamin J. (2015) Currency Power: understanding monetary rivalry, Princeton: Princeton University Press.

Cohen, Benjamin J. (2012) 'The Yuan Tomorrow? Evaluating China's Currency Internationalisation Strategy', New Political Economy 17(3): 361-71.

Cohen, Benjamin J. (1998) The Geography of Money, Ithaca: Cornell University Press.

Cohen, Benjamin J. (1971) The Future of Sterling as an International Currency, London: Macmillan.

Cohen, Benjamin J. and Tabitha M. Benney. (2014) 'What does the international currency system really look like?', Review of International Political Economy 21(4): 1017-41.

Cox, Robert W. (1981) 'Social Forces, States and World Orders: beyond international relations theory', Millennium 10(2): 126-55.

De Cecco, Marcello. (1974) Money and Empire: the international gold standard 1890-1914, Oxford: Blackwell.

Drezner, Daniel. (2009) 'Bad debts: assessing China's financial influence in great power politics', International Security 34(2): 7-45. 
Eichengreen, Barry. (2015) 'Sequencing Renminbi Internationalization', in Domenico Lombardi and Hongying Wang, eds, Enter the Dragon: China in the international financial system, pp. 85-112, Waterloo: Centre for International Governance Innovation.

Eichengreen, Barry. (1992) Golden Fetters: the gold standard and the Great Depression, 1919-1939, New York: Oxford University Press.

Eichengreen, Barry. and Marc Flandreau. (2012) 'The Federal Reserve, the Bank of England, and the Rise of the Dollar as an International Currency, 1914-1939', Open Economic Review 23(1): 57-87.

Eichengreen, Barry, Livia Chitu and Arnaud Mehl. (2018) How Global Currencies Work: past, present and future, Princeton: Princeton University Press.

Esping-Andersen, Gøsta. 1990 The Three Worlds of Welfare Capitalism. Cambridge: Polity Press.

Feis, Herbert. (1930/1964) Europe the World's Banker, New York: Augustus M. Kelley.

Fraser, Derek. (1984) The Evolution of the British Welfare State, second edition, London: Macmillan.

Germain, Randall. (1997) The International Organization of Credit: states and global finance in the world economy, Cambridge: Cambridge University Press.

Germain, Randall. and Herman Mark Schwartz. (2017) 'The Political Economy of Currency Internationalization: the case of the RMB', Review of International Studies 43(4): 765-87.

Germain, Randall and Herman Mark. Schwartz. (2014) 'The Political Economy of Failure: the euro as an international currency', Review of International Political Economy 21(5): 1095-122.

Gilbert, Bentley. (1970) British Social Policy: 1914-1939, Ithaca: Cornell University Press.

Gruin, Julian. (2013) 'Asset or Liability? The Role of the Financial System in the Political Economy of China's Rebalancing', Journal of Current Chinese Affairs 42(4): 73-104.

Hager, Sandy B. (2017) 'A Global Bond: explaining the safe-haven status of US Treasury securities', European Journal of International Relations 23(3): 557-80.

Hager, Sandy B. (2016) Public Debt, Inequality and Power: the making of a modern debt state, Oakland: University of California Press.

Harris, Bernard. (2004) The Origins of the British Welfare State, Basingstoke: Macmillan.

Helleiner, Eric. (2017) 'Downsizing the Dollar in the Age of Trump? The Ambiguities of Key Currency Status', Brown Journal of World Affairs XXIII(II): 9-27.

Helleiner, Eric. (1994) States and the Re-emergence of Global Finance, Ithaca: Cornell University Press.

Helleiner, Eric and Jonathan Kirshner, eds. (2014) The Great Wall of Money, Ithaca: Cornell University Press.

Helleiner, Eric and Jonathan Kirshner, eds. (2009) The Future of the Dollar, Ithaca: Cornell University Press.

Helleiner, Eric and Anton Malkin (2012) 'Sectoral interests and global money: Renminbi, dollars and the domestic foundations of international currency policy', Open Economies Review 23(1): 33-55.

Hung, Ho-fung. (2013) 'China: Saviour or challenger of the dollar hegemony?', Development and Change 44(6): 1341-61.

Howard, Christopher. (1997) The Hidden Welfare State, Princeton: Princeton University Press.

Imlah, Albert H. (1958/1969) Economic Elements of the Pax Britannica, New York: Russell and Russell.

Ito, Takatoshi. (2010) 'China as Number One. How about the Renminbi?', Asian Economic Policy Review 5(2): 249-76.

Jenkins, Paul and John Zelenbaba. (2012) 'Internationalization of the Renminbi: What it Means for the Stability and Flexibility of the International Monetary System', Oxford Review of Economic Policy 28(3): 512-31.

Kindleberger, Charles P. (1981) International Money, Boston: George Allen and Unwin.

Kwon, Edward. (2015) 'China's Monetary Power: internationalization of the Renminbi,' Pacific Focus 30(1): 78-102.

Langley, Paul. (2008) The Everyday Life of Global Finance: saving and borrowing in Anglo-America, New York: Oxford University Press.

Langley, Paul. (2002) World Financial Orders: an historical international political economy, London: Routledge.

Leung, Joe and Yuebin Xu (2015) China's Social Welfare: the third turning point, Cambridge: Polity Press.

Liao, Steven and Daniel McDowell. (2015) 'Redback Rising: China's bilateral swap agreements and Renminbi internationalization', International Studies Quarterly 59(3): 401-22.

Lombardi, Domenico and Anton Malkin (2017) 'Domestic Politics and External Financial Liberalization in China: the capacity and fragility of external market pressure', Journal of Contemporary China 26(108): 785-800.

Lombardi, Domenico and Hongying Wang, eds. (2015) Enter the Dragon: China in the international financial system, Waterloo: Centre for International Governance Innovation. 
McDowell, Daniel and David Steinberg. (2017) 'Systemic Strengths, Domestic Deficiencies: the Renminbi's future as a reserve currency', Journal of Contemporary China 26(108): 801-19.

McNally, Christopher. (2015) 'The political economic logic of RMB internationalization: a study in Sinocapitalism', International Politics 52(6): 704-23.

McNally, Christopher and Julian Gruin. (2017) 'Novel Pathways to Power? Contestation and adaptation in China's internationalization of the RMB', Review of International Political Economy 24(4): 599-628.

Noble, Charles. (1997) Welfare as We Knew It: a political history of the American welfare state, New York: Oxford University Press.

Norrlof, Carla. (2014) 'Dollar hegemony: a power analysis', Review of International Political Economy 21(5): 1042-70.

Otero-Iglesias, Miguel and Mattias Vermeiren (2015) 'China's state-permeated market economy and its constraints to the internationalization of the Renminbi', International Politics 52(6): 684-703.

Pettis, Michael. (2014) The Great Rebalancing, Princeton: Princeton University Press.

Schwartz, Herman Mark. (2009) Subprime Nation: American power, global capital and the housing bubble, Ithaca: Cornell University Press.

Seabrooke, Len. (2006) The Social Sources of Financial Power, Ithaca: Cornell University Press.

Sohn, Injoo. (2015) 'China's Monetary Ambitions: RMB Internationalization in Comparative Perspective', Korean Journal of International Studies 13(1): 181--206.

Steinberg, David. (2014) 'Why has China Accumulated Such Large Foreign Reserves', in E. Helleiner and J. Kirshner, eds, The Great Wall of Money, 71-98, Ithaca: Cornell University Press.

Stokes, Doug. (2014) 'Achilles' Deal: dollar decline and US grand strategy after the crisis', Review of International Political Economy 21(5): 1071-94.

Stopford, John and Susan Strange (1991) Rival States, Rival Firms: competition for world market shares, Cambridge: Cambridge University Press.

Strange, Susan. (1999) 'The Westfailure System', Review of International Studies 25(1): 345-54.

Strange, Susan. (1989) 'Towards a Theory of Transnational Empire', in Ernst-Otto Czempiel and James N. Rosenau, eds, Global Changes and Theoretical Challenges: approaches to world politics, 161-76, Lexington: Lexington Books.

Strange, Susan. (1988) 'The Future of the American Empire', Journal of International Affairs 42(1): 1-17.

Strange, Susan. (1985) 'Protectionism and World Politics', International Organization 39(2): 233-59.

Strange, Susan. (1971a) Sterling and British Policy, Oxford: Oxford University Press.

Strange, Susan. (1971b) 'The Politics of International Currencies', World Politics 23(2): 215-31.

Subramanian, Arvind. (2011) Eclipse: Living in the Shadow of China's Economic Dominance, Washington: Peterson Institute for International Economics.

Thimann, Christian. (2008) 'Global Roles of Currencies', International Finance 11(3): 211-45.

Trattner, Walter. (1989) From Poor Law to Welfare State: a history of social welfare in America, sixth edition, New York: Free Press.

Triffin, Robert. (1966) The World Money Maze: national currencies in international payments, New Haven: Yale University Press.

Triffin, Robert. (1960) Gold and the Dollar Crisis, New Haven: Yale University Press.

Wang, Daili, Yiping Huang and Gang Fan (2015) 'Will the Renminbi Become a Reserve Currency?', China Economic Journal 8(1): 55-73.

Wang, Hongying. (2014) 'Global Imbalances and the Limits of the Exchange Rate Weapon', in Eric Helleiner and Jonathan Kirshner, eds, The Great Wall of Money, 99-126, Ithaca: Cornell University Press.

Yu, Yongding. (2015) 'Understanding China's External Imbalances', China Economic Journal 8(1): 40-54.

Publisher's Note Springer Nature remains neutral with regard to jurisdictional claims in published maps and institutional affiliations.

Randall Germain is Professor of Political Science at Carleton University, Canada. He is the author of The International Organization of Credit (CUP, 1997) and Global Politics and Financial Governance (Palgrave, 2010). He recently edited Susan Strange and the Future of Global Political Economy (Routledge, 2016). 